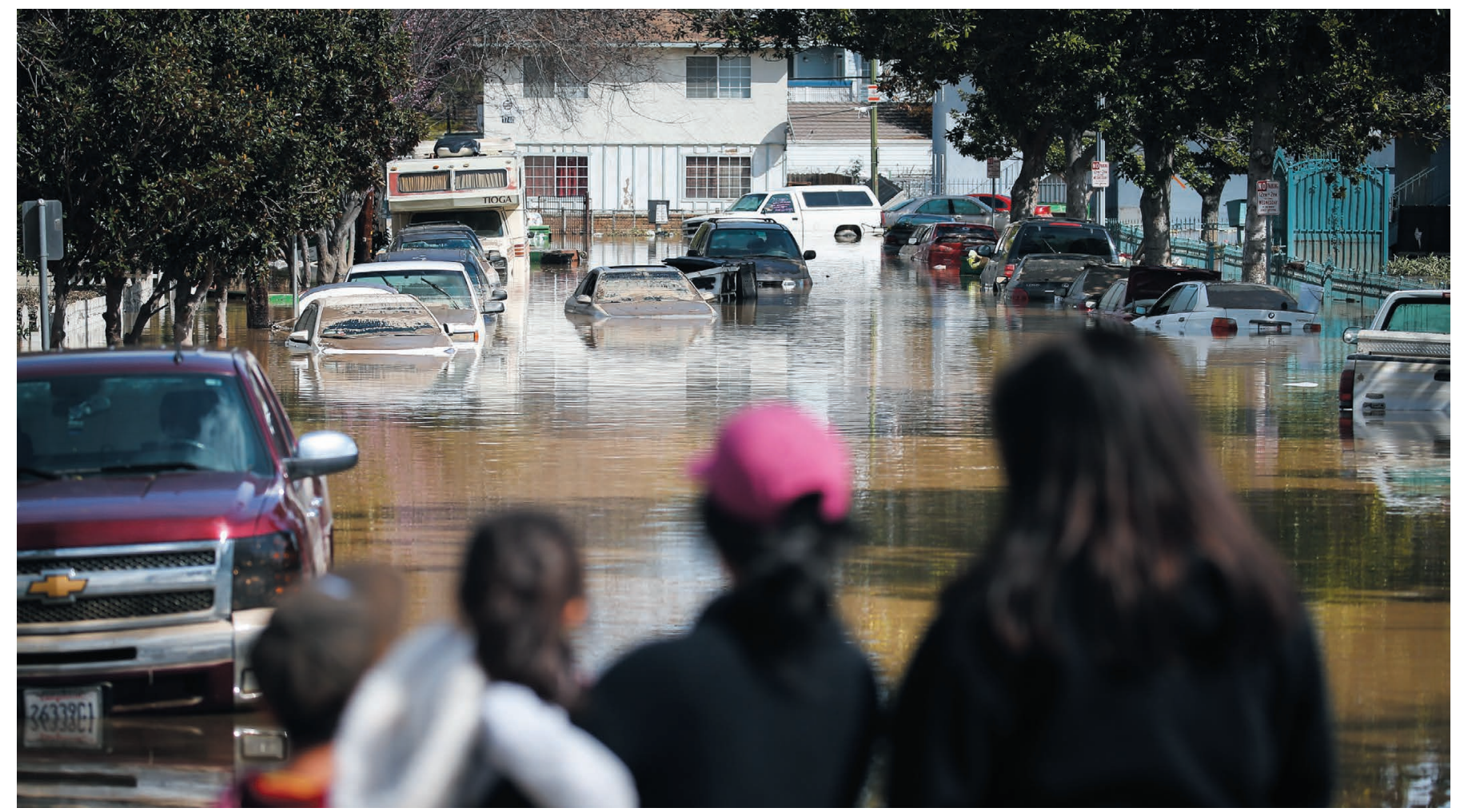

February floods forced residents of San Jose, California, to evacuate their homes and abandon vehicles.

\title{
Insurance companies should collect a carbon levy
}

\section{A surcharge on energy producers would fund climate adaptation and the low-carbon transition, suggest Anthony J. Webster and Richard H. Clarke.}

G overnments juggle too many interests to drive global action on climate change. But the insurance industry is ideally placed. With annual premiums amounting to between US\$4 trillion and $\$ 5$ trillion, or about $6 \%$ of world gross domestic product (GDP), the industry's future profitability hinges on limiting the risks of climate change.

Insurers are exposed to the consequences. Before Hurricane Harvey, which is likely to cost more than $\$ 100$ billion, in 2017 the United States experienced six storms, two floods and one freeze that each cost more than $\$ 1$ billion in damages. Severe floods, landslides and droughts have struck countries in the Americas and Africa, as well as India, China, Sri Lanka, Bangladesh, Thailand and Indonesia (www.reliefweb.int).

The costs of climate-related damage will grow as the world warms. For the United States, the impact on agriculture, crime, storms, energy, human mortality and labour will cost around $1 \%$ of GDP for each $1^{\circ} \mathrm{C}$ increase in global average temperature ${ }^{1}$. If a similar picture holds worldwide, each $1^{\circ} \mathrm{C}$ rise will cause about $\$ 1$ trillion of extra damage per year. For present temperatures above the 1980-2010 average, this equates to about $0.4 \%$ of world GDP - damages that are growing at around $0.1-0.2 \%$ per decade $e^{1,2}$.

As claims rise, so do premiums. Insurance cover may be cut, as was reported in 2005 after Hurricane Katrina hit Louisiana $^{2}$. Some places will become uninsurable. The poorest people will suffer most, despite having contributed least to atmospheric carbon dioxide. Developing countries such as war-torn Yemen, Afghanistan and those in sub-Saharan Africa have scant insurance cover, yet are among the nations at greatest risk from climate change.

Insurance companies can and should do more. They are central to the global climate challenge, helping to redress its consequences. Now they need to lead.
Here we propose that insurers collect a levy from energy producers according to the carbon intensity of their products. The funds generated should be invested in climate adaptation and low-carbon energy. This would be fair - polluters should redress the problems they create. The biggest beneficiaries of fossil fuels would then pay for the benefits they have derived at the expense of others, including future generations.

\section{WILLING AND ABLE}

The world's leading insurance companies have the will and the tools to push for a lowcarbon economy. In 2012, 66 chief executives of insurance firms endorsed the Principles for Sustainable Insurance (www.unepfi.org/ psi). These require the firms (and supporting organizations) to embed environmental and social concerns in board-level decisions, raise awareness of climate risks with clients and suppliers, work with governments and policymakers, and disclose progress. 
Insurers are used to collaborating with each other and with governments, and their role is broadening. The US National Flood Insurance Program, run by the Federal Emergency Management Agency, has covered buildings in threatened areas - such as along the US east coast - since the 1960s. Since 2016, UK legislation has required home insurers to pay a $£ 180$-million (US\$235-million) levy to a reinsurance scheme, Flood Re, to allow affordable insurance in flood-risk areas. And transport planner Gergely Raccuja's proposal to improve UK roads, which won the $£ 250,000$ Wolfson Economics Prize in July, asks car-insurance companies to calculate and collect a distance-based tax from road users. This would use mileage information that the insurers already obtain from their customers.

New products such as multi-year contracts are also being tried ${ }^{3}$. These can incentivize customers to adapt their properties, for example with flood-proofing. Cheap loans that help towards such adaptations may have even greater potential ${ }^{3}$.

Insurance can be a tool for regional development. Micro-insurance schemes protect farmers in developing countries from perils such as drought. In 2013, Indonesia passed a law obliging the national and local governments to protect farming through state-owned or private agricultural insurance. In July, the UK government announced a London Centre for Disaster Protection to provide expert insurance advice and help for developing countries.

Insurance companies are directing their vast funds towards low-carbon and adaptation projects. In 2014, a coalition of insurance companies pledged to invest $\$ 420$ billion over 5 years in energy efficiency, renewable energy and sustainable agriculture ${ }^{4}$. That sum compares well with the $\$ 10$ billion pledged by governments to the United Nations Green Climate Fund, or the tens of billions offered by the clean-energy initiatives Mission Innovation and the Breakthrough Energy Coalition over ten years. But it is barely $4 \%$ of the $\$ 2.3$ trillion per year that the International Energy Agency predicts must be invested in low-carbon technology to keep global warming to less than $2^{\circ} \mathrm{C}$.

Two other trends add pressure. Commercial banks, investment funds, university endowments and pension funds are shifting their portfolios away from fossil fuels and towards low-carbon options. They are driven by the fear that trillions of dollars of carbon-intensive assets could be 'stranded' as they become unburnable ${ }^{4}$. If assets lose value, so will companies and their investors, including insurance firms.

Meanwhile, legal challenges relating to climate change are becoming common ${ }^{5}$. There were 394 such disputes in the United Kingdom, United States, Australia and Canada

\section{ENERGY LEVY}

Insurers should collect a levy from energy producers according to the carbon intensity of their fuels or energy sources, and raise funds in proportion to the rising cost of damages from climate change.

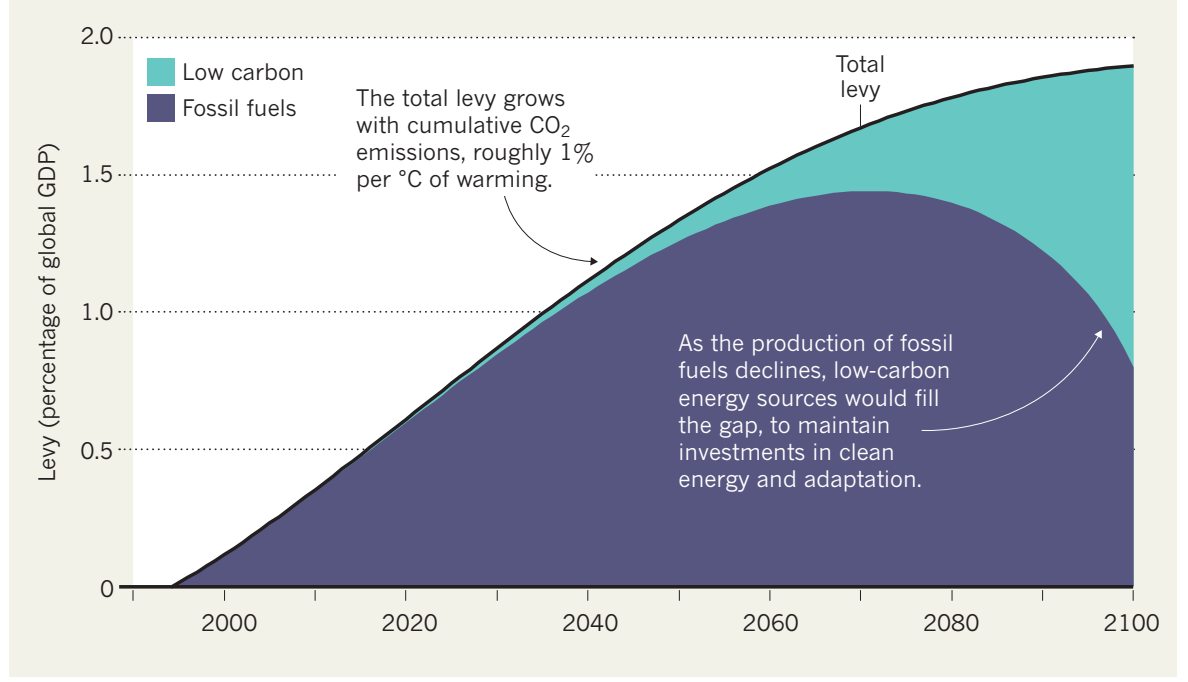

between 2013 and early 2015 (ref. 6). In June 2015, a Dutch court ordered the state to reduce greenhouse-gas emissions by at least $25 \%$ relative to 1990 levels by 2020 . In November, an Oslo court will hear a lawsuit filed against the Norwegian government by Greenpeace and other climate advocates, including US climate scientist James Hansen. They allege that issuing licences to drill for oil in the Arctic violates both the Paris climate agreement and article 112 of the Norwegian constitution, which requires the maintenance of a diverse and healthy environment for future generations.

In future, more courts are likely to agree with the overwhelming scientific evidence that cumulative $\mathrm{CO}_{2}$ emissions are increasing weather-related damage. As British lawyer Philippe Sands puts it: "We have gone well beyond the classical standards on the burden of legal proof, whether it be balance of probabilities, or beyond reasonable doubt."

Cases will multiply ${ }^{5,8}$, causing economic turmoil. The value of fossil-fuel companies and their investors will be hit. Insurance companies will be exposed through their investments and through third-party liability claims against companies they insure? The unintended global economic consequences would be damaging to everyone.

\section{POLLUTER PAYS}

To economists, climate change is an 'externality' - a social cost of fossil-fuel use that is not factored into its price. Conventional economic reasoning supposes that including this extra cost would lower demand for fossil fuels. Cap-and-trade schemes are the preferred means of doing this, by setting a limit on total emissions and by trading emissions permits. But so far, such market-driven approaches have led to modest carbon prices. Government interventions and gluts of permits have weakened the carbon markets.

Instead, we propose a levy managed by the insurance industry to fund adaptation and the low-carbon transition (see 'Energy levy'). Like a carbon or energy tax, it would have the advantage that the revenues go solely into adaptation and mitigation, not government or individual spending. It would have the same value internationally, be led by business and be set by an objective measure.

We believe that the levy could be paid voluntarily. Large petroleum companies have called for a realistic carbon price to increase the pace of low-carbon investments; an insurance levy would be equivalent. Companies that pay up will attract good publicity and may reduce the risks of future litigation. Governments could legislate that it must be paid, as the United Kingdom has done with Flood Re.

With full participation by energy producers, a levy would raise similar revenue to a $\$ 15$ per tonne carbon tax paid on all 32 billion tonnes of the energy sector's global carbon emissions. It would initially raise around $0.5 \%$ of world GDP per year for a $0.5^{\circ} \mathrm{C}$ rise above an agreed baseline global average temperature, such as that when the Intergovernmental Panel on Climate Change was formed (1988) or when the UN Framework Convention on Climate Change was adopted (1992). That equates to roughly $\$ 0.5$ trillion per year.

The levy would add just $5-7 \%$ to the current cost of US petrol, which should be acceptable to energy companies. But it will raise much more than the insurance industry's present \$420-billion plan for climate investment. The clear market signal will mobilize the financial resources of energy 
companies into low-carbon investments, and other investors will follow.

The levy would grow in proportion to the net cost of damages as the climate warms. The cost of cumulative $\mathrm{CO}_{2}$ emissions would be determined from the expected rise in

$z$ losses. An 'event attribution' methodology would be used - this determines the proportion of damages from each event that should be attributed to climate change, by calculating the probability of damage under different global climates ${ }^{10}$.

\section{DIRECTED INVESTMENTS}

Two further questions must be addressed: who should contribute, and who decides where revenues are directed?

Fossil-fuel extraction companies are obvious candidates to pay the levy. Increased costs will be passed on to consumers of fossil fuels, including the electricity, automotive, chemicals and plastics industries, encouraging the uptake of alternatives. And once the revenues from coal, gas and oil producers fall, other sources will be needed.

We propose that the levy should be aimed at energy producers according to their carbon intensity. It would account for both direct and indirect emissions - those involved in producing the fuel, technology and infrastructure (also known as embedded carbon). For example, if the carbon intensity of coal power is 80 times that of wind, then wind energy would initially pay about one-eightieth of the levy paid by a coal-fired power station per gigawatt hour of electricity production. Overall contributions would increase to retain "Rather than total revenues as allocating blame the carbon inten- for historical sity of energy falls. emissions, an

Targeting energy energylevy use discourages pays back the profligacy. And it benefits these is a proxy for tech- technologies nological develop- have brought." ment. It recognizes that all modern civilizations have a 'carbon inheritance': up to 250 years of industrial growth driven by fossil fuels has improved standards of living and health. Rather than allocating blame for historical emissions, an energy levy pays back the benefits these technologies have brought.

Setting the size of the levy according to damages linked to climate change - starting low and building up as impacts mount - is fair. It may also gain legal support. Larger revenues would accelerate the low-carbon transition, but a levy set too high could lead to fewer participants and might dent the economy. A compromise must be reached that the majority of energy companies and nongovernmental organizations will support.

The revenue raised would go to a wide

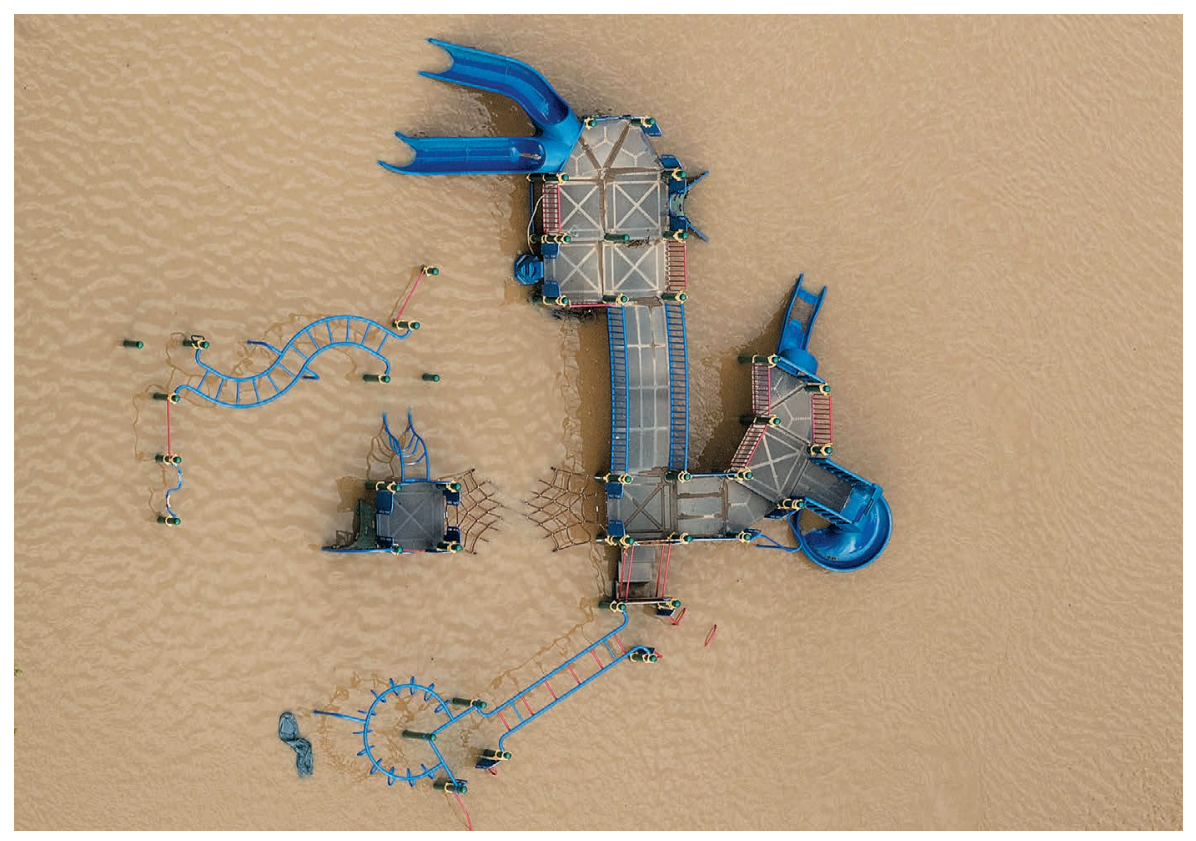

A playground structure inundated by flood water in February in San Jose, California.

range of projects, including producing and storing energy, and carbon capture and storage. A portion might go to basic research. The fraction going to adaptation should rise over time.

Thought needs to be given to how projects will be prioritized. Minimizing losses over the long term requires local knowledge of risks. Individual insurance providers could decide where the money goes, with regulations to limit its use. Business-led decisions can be justified on rational financial grounds, and are less vulnerable to changes in government policy. Some government involvement may be required to integrate decisions with social need. This could be encouraged through tax concessions or by legislating that insurers collect a levy for specific purposes, such as flooding.

\section{NEXT STEPS}

International organizations such as the Global Federation of Insurance Associations, the Association of British Insurers and the Geneva Association (a risk-management think tank) should discuss the willingness of the industry to organize a levy and explore how revenues might best be collected and redistributed. The Baden-Baden meeting of reinsurers in Germany in October offers an opportunity for preliminary talks.

Insurers, climate scientists and those who model extreme events must meet to determine how best to calculate the levy. They must agree on how carbon-intensity weighting will determine levy size for different energy producers, and whether a levy will account for the longer-term costs and risks from sea-level rise, for example.

Researchers should also determine how to encourage energy companies to voluntarily participate in a levy and how to get environmental organizations to support it. The answers to all these questions will need collating. The Geneva Association is well placed to arrange this, having access to funds, expertise and a network of insurers.

A levy applied by the insurance industry offers a business-led response to climate change. Its success is in everyone's interests.

Anthony J. Webster is a statistician and physicist at the Nuffield Department of Population Health, University of Oxford, UK. Richard H. Clarke is director of research at the carbon-pricing start-up Predict Ability, Farnborough, UK. e-mail:anthony.webster@physics.org

1. Hsiang, S. et al. Science 356, 1362-1369 (2017)

2. Clarke, R. H. Predicting the Price of Carbon (Predict Ability, 2016)

3. Maynard, T. \& Granger, N. Geneva Pap. Risk Insur. Issues Pract. 37, 318-339 (2012).

4. Fabian, N. Nature 519, 27-29 (2015).

5. Marjanac, S., Patton, L. \& Thornton, J. Nature Geosci. http://dx.doi.org/10.1038/ngeo3019 (2017).

6. Fisher, E., Scotford, E. \& Barritt, E. Mod. Law Rev. 80, 173-201 (2017).

7. Sands, P. J. Environ. Law 28, 19-35 (2016).

8. Lord, R., Goldberg, S., Rajamani, L. \& Brunnée, J. (eds) Climate Change Liability: Transnational Law and Practice (eds) (Cambridge Univ. Press, 2011).

9. Maynard, T. et al. Stranded Assets: The Transition to a Low Carbon Economy (Lloyd's, 2017); available at http://go.nature.com/2wayrjm

10. National Academies of Sciences, Engineering, and Medicine. Attribution of Extreme Weather Events in the Context of Climate Change (National Academies Press 2016); available at http:// go.nature.com/2gystwu

R.H.C. declares competing financial interests; see http://go.nature.com/2goa6ru 